\title{
Ornamental pteridophytes: an underexploited opportunity for the Sri Lankan floriculture industry
}

\author{
R.H.G. Ranil ${ }^{1}$, C.K. Beneragama ${ }^{1}$, D.K.N.G. Pushpakumara ${ }^{1 *}$ and D.S.A. Wijesundara ${ }^{2}$ \\ ${ }^{I}$ Department of Crop Science, Faculty of Agriculture, University of Peradeniya, Peradeniya. \\ ${ }^{2}$ Royal Botanic Gardens, Peradeniya.
}

\begin{abstract}
In the floriculture industry of Sri Lanka, the main operations are the production of cut foliage followed by rooted cuttings and potted plants for the export market. Cut foliage species include several genera and species of flowering plants and a few species of pteridophytes. The history of collection of pteridophyte flora in Sri Lanka dates back to 1672, however at present only a few of pteridophytes are used in the domestic and international floriculture markets. Sri Lanka is blessed with a high level of diversity of pteridophyte taxa, with an enormous diversity of plant form, appearance and foliage patterns. They thrive in many habitats and are suitable to be used in the floriculture industry of the country. Several species are suggested as suitable candidates for rational domestication and use in the floriculture industry. Effective domestication of the selected pteridophyte taxa will be useful for their in situ, ex situ and circa situm conservation through utilisation.
\end{abstract}

Keywords: Floriculture, ornamental plants, pteridophyte taxa, Sri Lanka.

\section{INTRODUCTION}

Floriculture industry began to play an important role in the Sri Lankan export sector during the early 1970s. This resulted from an attempt to diversify the exporting products with a view of gaining new sources of income and foreign exchange (Dhanasekera, 1998). Since then, the floriculture industry of Sri Lanka has been contributing to the national economy, generating a net foreign exchange worth of US \$9.5 and 14.1 million in 2012 and 2013, respectively. During the past decade, export-oriented floriculture industry of Sri Lanka has developed steadily (International Trade Centre, 2014). At present, Sri Lankan floricultural products are exported to 55 countries of which, the Netherlands and Japan being the major buyers making up two-thirds of the total floriculture exports of Sri Lanka (International
Trade Centre, 2014). It is evident that, during the past decade Sri Lanka has been gradually shifting towards exporting cut foliage and branches $(53 \%)$ and live plants (44\%) (hereafter collectively referred to as foliage plants, $97 \%$ ), even though Sri Lanka at the inception started export with cut-flowers (International Trade Centre, 2014). In 2013, Sri Lanka was ranked $52^{\text {nd }}$ in the global floriculture trade sharing a little less than $0.1 \%$ of the total. However, the country was ranked $21^{\text {st }}$ in the global cut foliage trade in 2013, contributing to $0.6 \%$ of the total cut foliage business (International Trade Centre, 2014).

Currently, several plant genera belonging to the families Araceae (e.g. Aglaonema, Anthurium, Dieffenbachia, Monstera, Philodendron, Scindapsus, Syngonium), Araliaceae (e.g. Polyscias, Schefflera), Arecaceae (e.g. Areca, Cocos, Caryota, Dypsis, Livistona), Asparagaceae (e.g. Aspidistra, Cordyline, Dracaena, Hosta, Ophiopogon, Pleomele, Sansevieria), Euphorbiaceae (e.g. Codiaeum), Heliconiaceae (e.g. Heliconia), Marantaceae (e.g. Calathea, Ctenanthe, Maranta) and Nepenthaceae (e.g. Nepenthes) dominate the Sri Lankan foliage plant assortment in the world trade (Export Development Board, 2011). Only a few genera of pteridophytes (e.g. Adiantum, Nephrolepis and Rumohra) are being occasionally exported as ornamental foliage plants (Export Development Board, 2011).

\section{Need for introduction of new pteridophytes to the floriculture industry}

Sri Lankan export market has been relying on the same set of foliage plant species for decades. Thus, diversification of floricultural products by introducing new species and new varieties of old species will be of 
paramount importance to flourish in the export market and reduce the risk of dependence on the same products. Dracaena sanderiana Sander provides a classical example for the risk of dependence on the same product over years. Until recently, Sri Lanka was able to produce a considerable volume of this species for the export market. With the recent expansion of the floriculture business in China, Sri Lanka is now facing market competition for D. sanderiana (Personal Communication, Mr. Dilip De Silva, Serandib Horticulture Private Limited., Kalagedihena, Sri Lanka, 20 September 2013).

\section{Status of pteridophyte research in Sri Lanka}

The region including Sri Lanka and the Western Ghats of India is one of the 34 global biodiversity hotspots identified in the world, based on exceptionally high species diversity combined with a high level of endemism and multiple threats faced by the natural ecosystems (Mittermeier et al., 2005). Among Asian countries, Sri Lanka is second only to Taiwan in terms of the number of pteridophyte species per 10,000 square kilometres (Ranil et al., 2008a). As of 2006, about 348 pteridophyte taxa from 30 families have been recorded from Sri Lanka (Shaffer-Fehre, 2006), with $14 \%$ endemism (Ranil et al., 2008a). The reason for such a high level of species diversity and exceptionally high endemicity of pteridophytes is largely due to the island nature of the country.

The recorded history of pteridological collections in Sri Lanka dates back to 1672. The first phase of pteridological studies in the country was the cataloguing of genera and species, which began during the late $18^{\text {th }}$ and early $19^{\text {th }}$ centuries. From the mid 1950 s to 1982 , pteridophyte research included cytological studies and monographs (Manton \& Sledge, 1954; Sledge, 1982). Recently, various Sri Lankan researchers have published work on peteridophytes, culminating in the publication of A Revised Handbook to the Flora of Ceylon, volume XV: Fern and Fern-Allies (Shaffer-Fehre, 2006). However, a comprehensive research on the ecology, genetics and reproductive biology of a selected pteridophyte family has been started only recently (Ranil et al., 2010a; 2010b; 2010c; 2011). Parallel to such studies, the ethanobotanical uses, domestication and conservation of pteridophytes have also been recently initiated aiming at the utilisation and in situ and ex situ conservation of pteridophytes in Sri Lanka (Ranil et al., 2011).

More recently for the first time, the threatened status of pteridophyte flora has been systematically assessed and included in the National Red List of Sri Lanka 2012 (Ranil \& Pushpakumara, 2012). Accordingly, about $6,12,26$ and $21 \%$ of species are identified as critically endangered and possibly extinct, critically endangered, endangered and vulnerable, respectively.

\section{Use of pteridophytes in Sri Lanka}

Despite the long history of pteridophyte collections, the uses of pteridophytes in the country are limited. Although pteridophytes are not widely used in Sri Lanka, it has been reported that pteridophytes have the ability to provide food, medicine, fibre, supportive poles, craft and building materials. They are also used for ornamental and decoration purposes worldwide (Croft, 1985). Although pteridophytes are of minor economic significance to mankind today, the great benefits of the past eras when pteridophytes dominated the world's vegetation and contributed much to the world's coal reserves will always be important (de Winter \& Amoroso, 2003). Despite the limited use of pteridophytes as ornamental plants in Sri Lanka, their use as ornamental plants is very popular throughout the world (de Winter \& Amoroso, 2003). A review of the uses of pteridophytes has revealed that over 100 applications of various species are common on the global scale (May, 1978). A survey on uses of pteridophytes by communities around the Kanneliya Forest Reserve in Sri Lanka revealed that several species have been used for medicinal, ornamental and food purposes (Ranil \& Pushpakumara, 2005). Further, results of the study also revealed that pteridophytes collected from adjacent forest communities from the wild did not regenerate suggesting that for some species, an immediate and coordinated strategy for conservation is required.

\section{Diversity of pteridophytes with ornamental features}

Based on the authors' research on pteridophyte flora in the country for over a decade, it can be concluded that they are distributed in different habitats with a strong adaptability for various environmental conditions. Under natural environment, most species are shade and moisture loving and grow in the interiors of forests. Some species are sun loving and occur in canopy openings and on roadside banks. The majority of pteridophytes can be used as ornamental plants since many of them can be grown well in shady and moist environments.

Pteridophytes grow in diverse habitats where a majority of them are ground based; some are epiphytic and others are lithophytic (Jones, 1987). Due to their diverse habitats, these species can be grown well on the ground or in pots, as epiphytes on tree trunks or hanging baskets or on rocks as lithophytes (Table 1). Petridophytes can be grown as ornamental plants indoors or outdoors under various shade levels. 

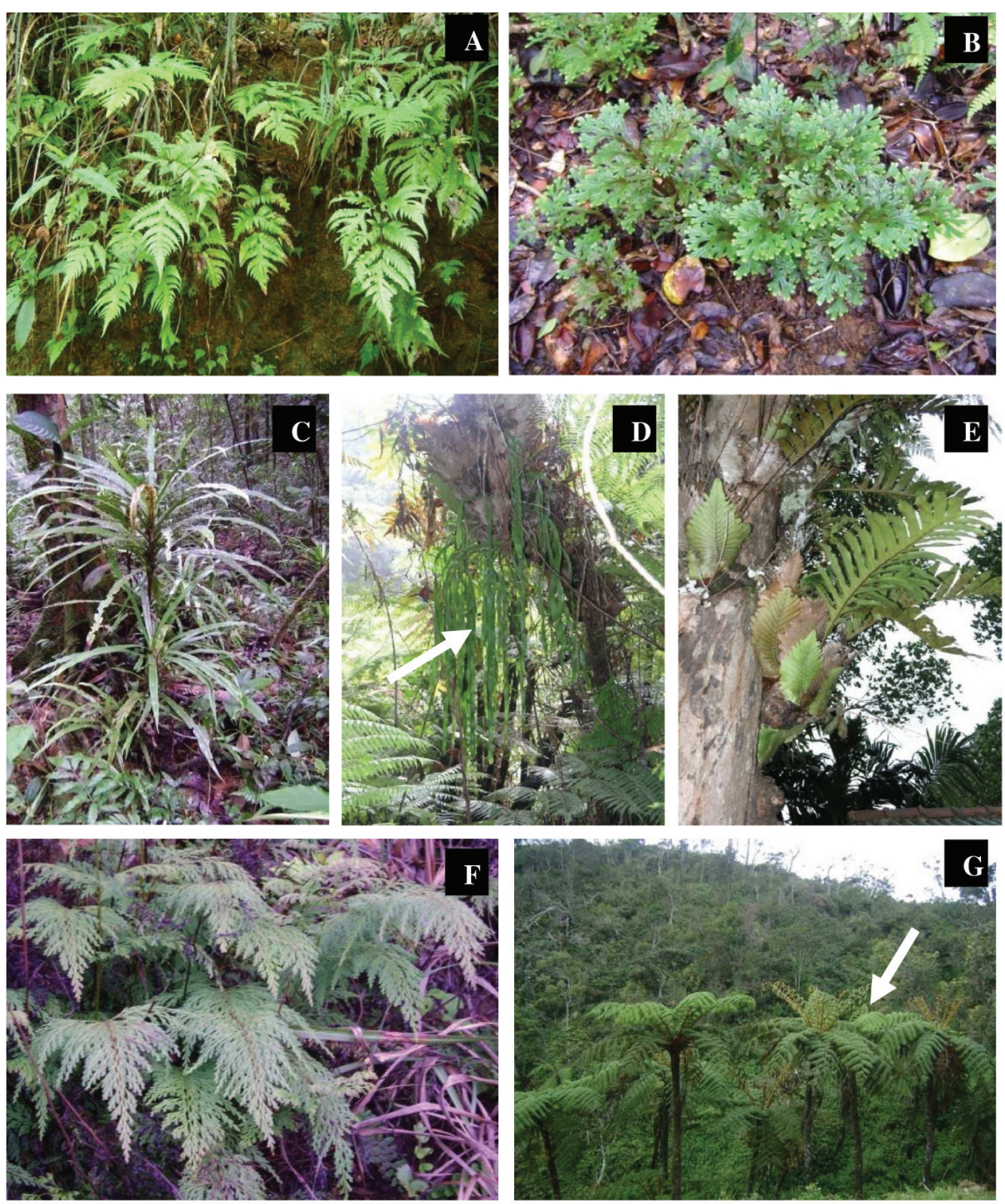

Figure 1: A few potential ornamental pteridophytes growing in natural environments of Sri Lanka.

A: Tectaria thwaitesii (Bedd.) Ching; B: Selaginella brachystachya (Hook. \& Grev.) Spring;

C: Cyathea sinuata Hook. \& Grev.; D: Ophioglossum pendulum L.; E: Drynaria quercifolia (L.) J. Sm.;

F: Sphenomeris chinensis (Linn.) Maxon and G: Cyathea crinita (Hook.) Copel

Although pteridophytes do not produce flowers, they can be grown as ornamental plants because of their aesthetic value due to elegant foliage of varying heights, shapes and textures that grace delicate beauty (Jones, 1987). Their ornamental foliage structure varies from the simple strap-shaped fronds to the plumose froth of the finely divided cultivars. The fronds of many ferns keep well in water and they can be added to floral arrangements as a filler material (Jones, 1987). The fronds of many ferns can also be used in dried arrangements and in the relatively modern innovation of gold or silver painted arrangements.
Pteridophytes show a wide variation in plant morphology and ornamental features. As an example, endemic Cyathea sinuata Hook. \& Grev. is the only scaly tree fern species in the world, which has simple leaves (fronds) out of about 500 known Cyathea species worldwide (Kramer, 1990; Figure 1). C. sinuata has a high potential to be developed as a pot plant due to its unique leaf morphology and plant architecture whereas $C$. gigantia (Wall. ex. Hook.) Holttum and C. crinita (Hook.) Copel., (Figures $1 \mathrm{C}$ and $1 \mathrm{G}$ ) are suitable to be grown in upcountry environments as outdoor plants. 


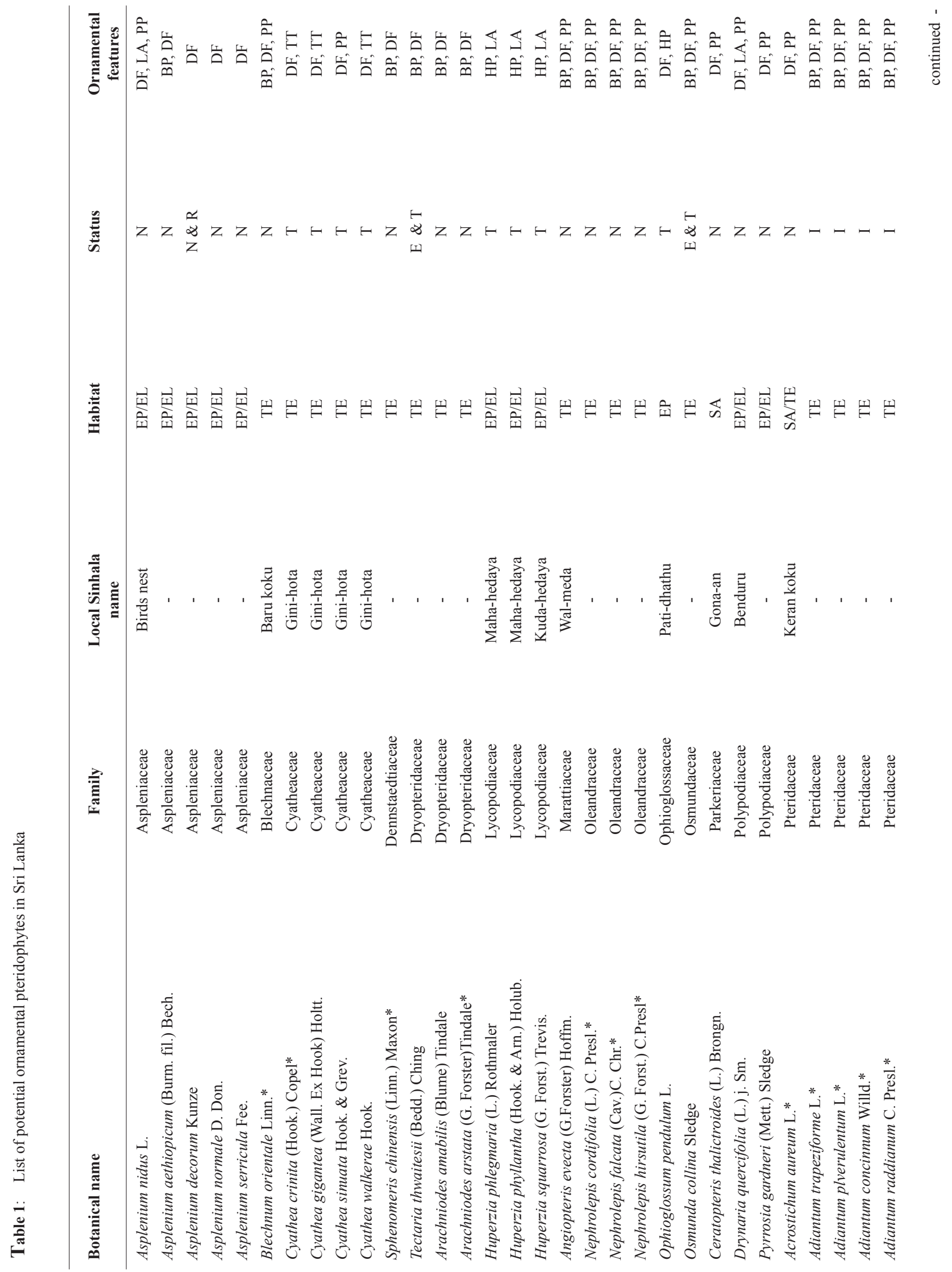




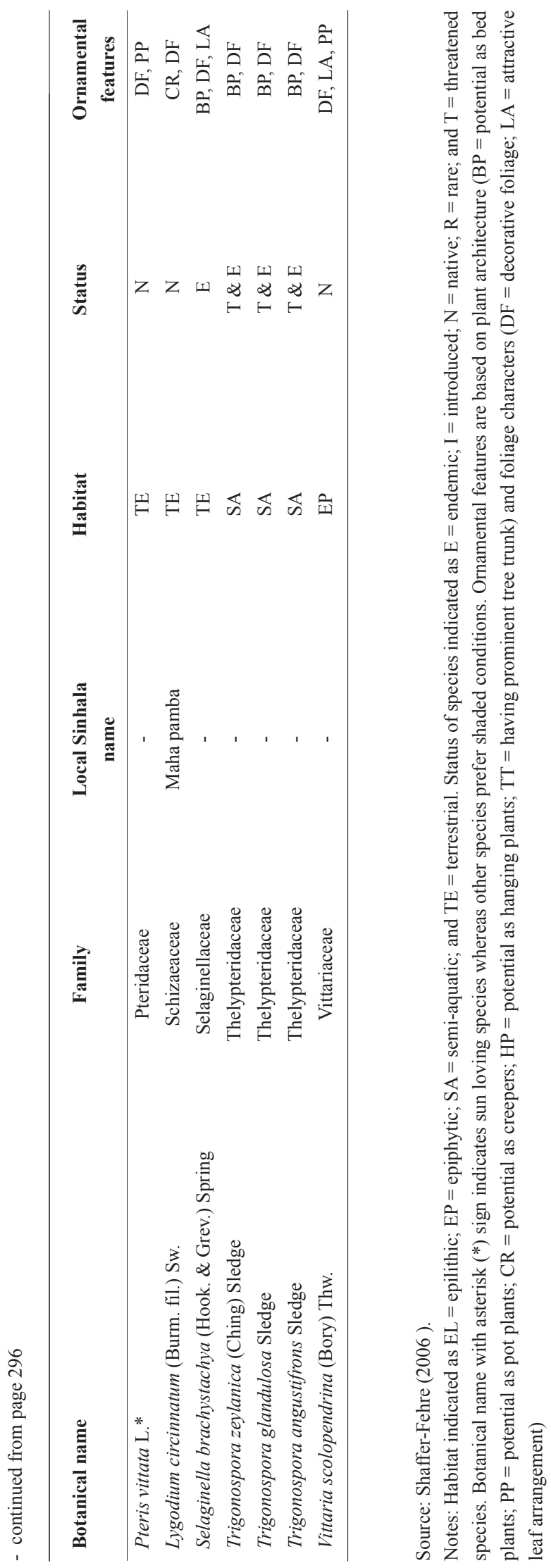

Based on mature plant size, ornamental pteridophytes can be divided into five categories (Jones, 1987), namely (i) giant pteridophytes (more than $80 \mathrm{~cm}$ tall); (ii) medium pteridophytes ( $30-80 \mathrm{~cm}$ tall); (iii) small pteridophytes (usually less than $30 \mathrm{~cm}$ tall); (iv) tiny pteridophytes with membrane foliage (they are very small with transparent foliage); and (v) climbing pteridophytes (Figures 1 and 2 ). Giant pteridophytes can be planted in parks, scenic areas, lawns, along water bodies, under trees, and around buildings whereas medium size pteridophytes are excellent plants for side walls and buildings. They are also good indoor plants for both quiet and busy foot traffic areas, such as theatres and shopping centres. Small pteridophytes can be used as miniature bonsai, or small potted plants for office, balcony and artificial rocky mounts. Giant, medium and small pteridophytes can also fit very well into boarders. Climbing pteridophytes can be used for ground cover, hanging and other designed baskets. Tiny pteridophytes are good for high humidity areas .

Pteridophytes provide many opportunities for the Sri Lankan floriculture sector due to the following: (i) production is non-seasonal, thus year-round supply is possible, (ii) for most of the species, the commercial ventures are low-input and low-labour demanding, (iii) they are far less prone to pests and diseases, (iv) not necessarily be grown inside green houses, instead, net houses are sufficient for multiplication, (v) new export markets can be developed particularly in the East Asia (Dasgupta \& Dadlani, 2011), (vi) rapidly developing domestic demand for foliage, particularly for weddings, and (vii) possibility of growing pteridophytes in most of the agro-ecological regions of Sri Lanka if sufficient shade and moisture is guaranteed. These favourable features of pteridophytes can be exploited in the floriculture industry of Sri Lanka through a coordinated strategy.

\section{Phytoremediation potential of pteridophytes}

In addition to the ornamental value, the discovery of Pteris vittata L. (Chinese brake fern) and related species to hyper-accumulate arsenic in their fronds has led to the development of environmentally-friendly, cost-effective and aesthetically pleasing phytoremediation technology for arsenic contaminated sites (Rathinasabapathi et al., 2006). As Bhupinder (2009) highlighted, aquatic ferns exhibit exorbitant potential to remove various contaminants including heavy metals, organic compounds, and radio-nuclides from the environment. Pteridophytes also have the capacity to purify air by absorbing toxic gasses other than carbon dioxide, specially in indoor 
environments. Wolverton and Wolverton (1993) have identified Nephrolepis exaltata as an effective plant to remove formaldehyde gas.

\section{Potential ornamental pteridophytes and their domestication in Sri Lanka}

At present, use of pteridophytes in the Sri Lankan floriculture industry is limited and dominated by a few exotic ferns such as Nephrolepis spp., Adiantum spp., Davallia spp., Asplenium spp., and Platicerum spp. Ranil and Pushpakumara (2005) revealed that some of the native species such as Asplenium nidus L. (Figure 2E), Cyathea crinita (Hook.) Copel. (Figure 1G, 2A and 2B), Cyathea walkerae Hook. (Figure 2C), Drynaria quercifolia (L.) J. Smith (Figure 1E), Ophioglossum pendulum L. (Figure 1D) and Huperzia sp. are grown as ornamental plants by local communities in both outdoor and indoor environments. Cyathea crinita (Figure 1G, 2A and 2B) is commonly used in the Nuwara Eliya District.

According to de Winter \& Amoroso (2003), a successful ornamental pteridophyte species should have the following common characteristics: (i) closely placed fronds, which give them a full foliage look; (ii) symmetry in overall outline; (iii) small to medium size; (iv) an evergreen habit; (v) at least one unusual characteristic that make them special, i.e. colour, texture or shape;
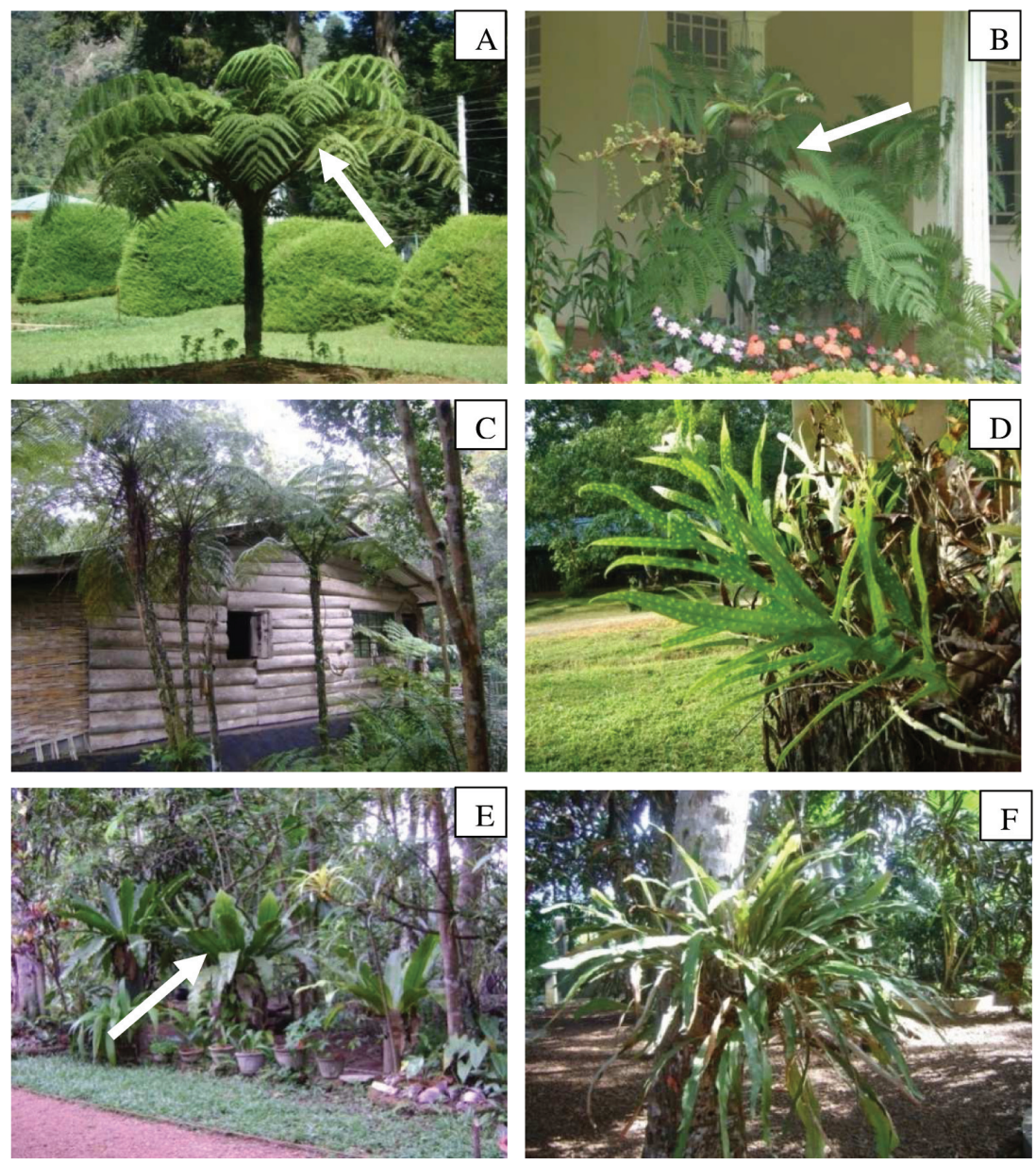

Figure 2: Pteridophytes grown in indoor and outdoor environments in Sri Lanka

$\mathrm{A}$ and $\mathrm{B}$ are Cyathea crinita (Hook.) Copel in outdoor and indoor environment, respectively; C, D, E and F are endemic Cyathea walkerae Hook. in outdoor environment, native Microsorum scolopendrium in outdoor environment, common epiphytic Asplenium nidus L. in outdoor environment, and endemic Pyrrosia gardneri (Mett.) Sledge in outdoor environment, respectively. 
and (vi) can conveniently be propagated by both sexual and asexual methods. Further as Hoshizaki (1992) noted, the pteridophytes should be able to adapt to pest and disease control measures and they should also not be easily damaged during transport from the growers point to the market place. Based on our studies and the above criteria, the Sir Lankan pteridophyte species listed in Table 1 are identified as potential species for domestication and for developing and popularisation as ornamental peteridophytes for Sri Lankan floriculture industry.

To explore the potential of these under-utilised species, systematic selection, multiplication, breeding and improvement are needed. Some petridophytes have successfully been acclimatised and propagated under favourable conditions (Jones, 1987).

Proper domestication and utilisation, which includes propagation and cultivation of pteridophyte species of floricultural value will aid ex situ conservation of such species. For example, Huperzia phlegmaria (L.) Rothm. (locally known as Maha hedaya) and Huperzia squarrosa (G. Forst.) Trevis. (locally known as Kuda hedeya) can be introduced as ornamental plants through propagation and cultivation. This in turn will help the overall conservation of the species.

In Sri Lanka, as far as the use of fern species is concerned, in almost all cases, the plants are collected from the wild, potted and planted or sold. No previous research has been conducted locally on vegetative propagation or spore germination and subsequent development of sporophytes on artificial media to facilitate cultivation. The vegetative propagation methods include the use of rhizomes (e.g. Davalia spp. and Drynaria spp.), bulbils (e.g. Asplenium spp.), frond tips (e.g. Adaiantum spp.), offsets (e.g. Cyathea spp.), stipules (e.g. Angiopteris spp.), tubers (e.g. Nephrolepis spp.), root buds (e.g. Ophioglossum spp.) and layering (e.g. Lygodium spp.) as planting starting material. The sexual method of propagation involves raising plants from spores. As Linsay (1994) suggested, the propagation of pteridophytes via spores are more advantageous than the vegetative modes for economic and transport reasons.

\section{Way forward}

A recent study by Ranil et al. (2008b) provides encouraging results on effective spore germination media, gametophyte morphology and the successful raising of sporophytes from gametophytes, and their transfer to general growth media with $C$. walkerae (Figure 3), C. sinuata and C. sledge. These species are difficult to regenerate even under natural conditions. Such techniques with modifications can be used to propagate and cultivate ferns as ornamental plants. However, some species require a unique environment and propagation techniques, which needs to be investigated. In this regard, species prioritisation and their inclusion into the national floricultural research agenda is a must. Further, several pteridophytes can be developed for export purposes. Therefore, a network of ornamental nurseries and their active involvement is also required.

However, before developing and popularising such species as ornamental plants, there should be a
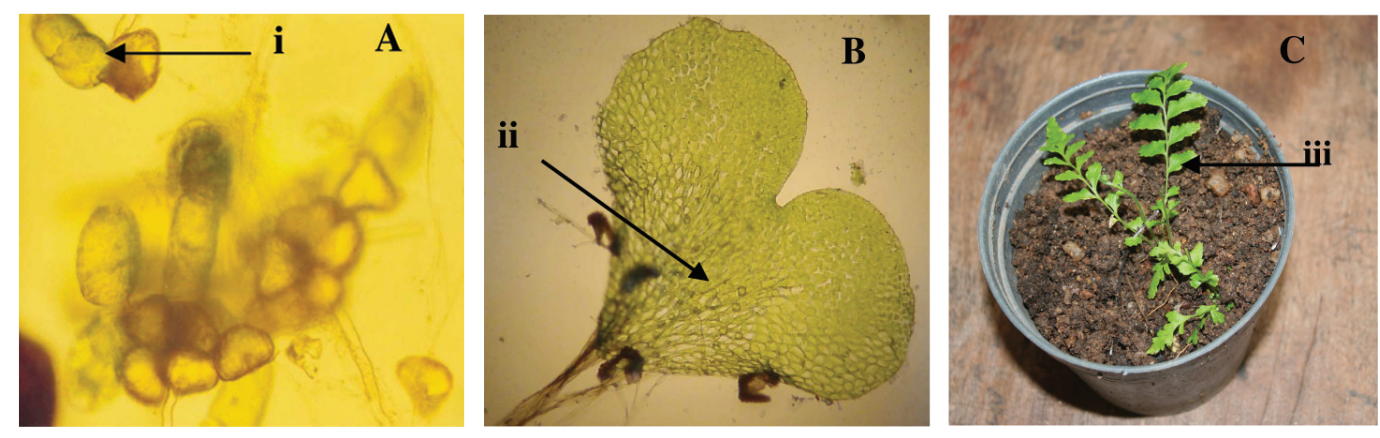

Figure 3: Stages of spore germination protocols for Cyathea walkerae Hook.

A: Germinated spores on media (i: prothalial cells emerge from spore) (7 - 10 days after sowing, DAS) $(\times 100)$; B: Caudate shape gametophytes (ii: antheridia) (45 DAS) $(\times 100)$; C: Juvenile sporophyte on general potting media (iii: frond) $(4-6$ months after sowing $)(\times 1 / 10)$ 
comprehensive study on their climatic and soil requirements, nutrient requirements, propagation methods (spores, vegetative methods, tissue culture etc.), keeping quality, customer preference and the potential to cultivate under different environmental conditions. At the same time, it is important to consider their conservation and legal status before popularising such species. Public awareness programmes on the conservation and sustainable utilisation of ferns should be initiated promoting in situ and ex situ conservation and domestication. Activities such as short courses will bring the much needed knowledge of new species and new directions for the Sri Lankan floriculture industry. This effort will also solve the conservation issues of threatened and endangered pteridophyte species in Sri Lanka.

\section{REFERENCES}

1. Bhupinder D. (2009). Salvinia: an aquatic fern with potential use in phytoremediation. International Journal of Science and Technology 4: $23-27$.

2. Croft J.R. (1985). Ferns and fern allies. Fresh Water Plants of Papua New Guinea (eds. G.J. Leach \& P.L. Osborne), pp. 33 - 74. University of Papua New Guinea Press, Port Moresby, Papua New Guinea.

3. Dasgupta S. \& Dadlani N.K. (eds) (2011). Report of the Expert Consultation on Floriculture Development in Asia. Kunming, China, 7 - 9 January, 2010. Food and Agriculture Organisation of the United Nations Regional Office for Asia and the Pacific, Bangkok, Thailand, pp. $22-23$.

4. de Winter W.P. \& Amoroso V.B. (2004). Plant Resources of South-East Asia No 15(2). Criptogams: Fern and Fern Allies. Backhuys Publishers, Leiden, The Netherlands.

5. Dhanasekera D.M.U.B. (1998). Cut Flower Production in Sri Lanka, pp. 18. Food and Agriculture Organisation of the United Nations Regional Office for Asia and the Pacific, Bangkok, Thailand.

6. Export Development Board (2011). Sri Lanka Directory of Exporters-2011. Available at http://www.srilankaexporters. lk/index.php, Accessed 20 October 2013.

7. Hoshizaki B.J. (1992). The potential for new ferns introduction. In: Fern horticulture: Past, Present and Future Perspective. Proceedings of the International Symposium on Cultivation and Propagation of Pteridophytes (eds. J.M. Ide, A.C. Jermy \& A.M. Paul). The British Pteridological Society, London, UK, pp. $97-103$.

8. International Trade Centre (2014). Trade Statistics for International Business Development. Market Analysis and Research, International Trade Centre (ITC); Palais des Nations; CH - 1211 Geneva 10, Switzerland.

9. Jones D.L. (1987). Encyclopedia of Ferns: An Introduction to Ferns, Their Structure, Biology, Economic
Importance, Cultivation and Propagation. Timber Press, Portland, Oregon.

10. Kramer K.U.(1990). Cyatheaceae. The Families and Genera of Vascular Plants: Pteridophyte and Gymnosperm (ed. K. Kubitzki), pp. 69 - 74. Springer-Verlag, New York, USA. DOI: http://dx.doi.org/10.1007/978-3-662-02604-5_18

11. Linsay J. (1994). Account of germination and raising of ferns from the seed. Transactions of the Linnean Society of London 2: 93 - 100.

DOI: http://dx.doi.org/10.1111/j.1096-3642.1794.tb00247.x

12. Manton I. \& Sledge W.A. (1954). Observations on the cytological and taxonomy of the Pteridophyte flora of Ceylon. Philosophical Transactions of the Royal Society of London. Biological Sciences 238(Series B): 127 - 185.

13. May L.W. (1978). The economic uses and associated folklore of ferns and fern allies. The Botanical Review 44(4): $491-528$.

DOI: http://dx.doi.org/10.1007/BF02860848

14. Mittermeier R.A., Gil P.R., Hoffman M., Pilgrim J., Brooks T., Mittermeier C.G., Lamoreux J. \& de Fonseca G.A.B. (2005). Hotspots Revisited: Earth's Biologically Richest and Most Threatened Terrestrial Eco-regions. Conservation International, Washington DC, USA.

15. Ranil R.H.G. \& Pushpakumara D.K.N.G. (2012). Taxonomy and conservation status of Petridophyte flora of Sri Lanka. The National Red List 2012 of Sri Lanka: Conservation Status of Fauna and Flora (eds. D.K. Weerakoon \& S. Wijesundara), pp. 148 - 164. Ministry of Environment, Colombo, Sri Lanka.

16. Ranil R.H.G. \& Pushpakumara D.K.N.G. (2005). Uses of Pteridophyte flora in Sri Lanka. Proceedings of the Tenth Annual Forestry and Environment Symposium 2005. Department of Forestry and Environmental Science, University of Sri Jayawardenapura, p. 28.

17. Ranil R.H.G., Pushpakumara D.K.N.G., Janssen T., Fraser-Jenkins C.R. \& Wijesundara D.S.A. (2011). Conservation priorities of tree ferns of Sri Lanka. Taiwania 56(3): $201-209$.

18. Ranil R.H.G., Pushpakumara D.K.N.G., Janssen T., Fraser-Jenkins C.R. \& Wijesundara D.S.A. (2010a). Cyathea sledgei (Cyatheaceae): a new species of tree-fern from Sri Lanka. Fern Gazette 18(7): 318 - 325.

19. Ranil R.H.G., Pushpakumara D.K.N.G., Janssen T., Wijesundara D.S.A. \& Dhanasekara D.M.U.B. (2010b). Cyathea srilankensis Ranil: a new tree fern species from Sri Lanka. American Fern Journal 100(1): 39 - 44. DOI: http://dx.doi.org/10.1640/0002-8444-100.1.39

20. Ranil R.H.G., Pushpakumara D.K.N.G., Samita S., Wijesundara D.S.A. \& Dhanasekara D.M.U.B. (2010c). Variation of three co-occurring taxa of the genus Cyathea and their relationship in Sinharaja and Kanneliya lowland rain forests of Sri Lanka. Tropical Agricultural 
Research 21(2): $134-146$.

DOI: http://dx.doi.org/10.4038/tar.v21i2.2595

21. Ranil R.H.G., Pushpakumara D.K.N.G. \& Wijesundara D.S.A. (2008a). Present status of taxonomic research and conservation of endemic pteridophytes in Sri Lanka. Proceedings of the $4^{\text {th }}$ Symposium on Asian Pteridology and Garden Show (ed. V.B. Amoroso). Central Mindanao University, Musuan, Bukidnon, The Philippines, pp. 84 - 93.

22. Ranil R.H.G., Pushpakumara D.K.N.G., Wijesundara D.S.A. \& Dhanasekara D.M.U.B. (2008b). Domestication of Cyathea walkerae Hook. Sri Lankan Journal of Agricultural Science 45: 47 - 58.

23. Rathinasabapathi B., Ma L.Q. \& Srivastav M. (2006). Arsenic hyper-accumulating ferns and their application to phytoremediation of arsenic contaminated sites. Floriculture, Ornamental and Plant Biotechnology, volume II. Global Science Books, UK.

24. Shaffer-Fehre M. (2006). A Revised Handbook to the Flora of Ceylon, volumes XV, part A: Ferns and Fern Allies. Science Publishers, Enfield, NH, USA.

25. Sledge W.A. (1982). An annotated checklist of the pteridophyte of Ceylon. Botanical Journal of the Linnaean Society 84: 1 - 30 .

DOI: http://dx.doi.org/10.1111/j.1095-8339.1982.tb00357.x

26. Wolverton B.C. \& Wolverton J.D. (1993). Plants and soil microorganisms: removal of formaldehyde, xylene, ammonia from the indoor environment. Journal of the Mississippi Academy of Sciences 38(2): $11-15$. 